\title{
Elaboración de queso tipo panela con extracto de hoja de ortiga y su comparación de parámetros fisicoquimicos
}

\author{
Elaboration of Panela-type Cheese with Nettle Leaf Extract (Euphorbiaceae Cnidoscolus \\ aconitifolius) for the Comparison of Physical-chemical Parameters
}

\section{Uriel González-Lemus ${ }^{a}$, Aurora Quintero-Lira ${ }^{a}$, Javier Piloni-Martini ${ }^{a}$, Rafael G. Campos- Montiel $^{b}$, Abigail Reyes-Munguía ${ }^{b}$, María A. Martínez-Trujillo ${ }^{a}$, Norma Güemes-Vera ${ }^{a}$}

\begin{abstract}
:
The nettle (Euphorbiaceae Cnidoscolus aconitifolius) belonging to the angiosperms, grows in the center-southeast of Mexico. This plant is used in an artisanal way in some municipalities of Hidalgo for the production of fresh cheese. In the following work, the vegetal extract of the leaf was obtained, which was used as a coagulant at different concentrations $(0.75 \%$ and $1.0 \%)$ for the coagulation of the milk at a temperature of $90^{\circ} \mathrm{C}$. The coagulant of animal origin (Chymosin) was used to prepare the control. All the treatments were elaborated with bovine milk as substrate and in conditions of $\mathrm{pH} 6.5$, where the comparison of the different physicalchemical parameters (Protein, fat, ash and moisture) of the cheeses obtained with the vegetal extract and the chymosin. The results showed that the treatment made with the leaf extract $(1 \%)$ presented a higher percentage of protein and fat $(18.16 \%$ and $20.90 \%$ respectively) and lower moisture content $(61.90 \%)$.
\end{abstract}

Keywords:

Nettle, Hidalgo, Vegetable coagulant, Chymosin

Resumen:

La ortiga (Euphorbiaceae Cnidoscolus aconitifolius) perteneciente a las angiospermas, crece al centro-sureste de México. Esta planta es utilizada de manera artesanal en algunos municipios de Hidalgo para la elaboración de queso fresco. En el siguiente trabajo, se obtuvo el extracto vegetal de la hoja, el cual se utilizó como coagulante a diferentes concentraciones $(0.75 \%$ y $1.0 \%)$ para la coagulación de la leche a una temperatura de $90^{\circ} \mathrm{C}$. Para la elaboración del control se utilizó coagulante de origen animal (quimosina). Todos los tratamientos fueron elaborados con leche bovina como sustrato y en condiciones de pH 6.5, donde se realizó la comparación de los distintos parámetros físico-químicos (Proteína, grasa, cenizas y humedad) de los quesos obtenidos con el extracto vegetal y la quimosina. Los resultados mostraron que el tratamiento elaborado con el extracto de hoja (1\%) presentó mayor porcentaje de proteína y grasa $(18.16 \%$ y $20.90 \%$ respectivamente) y menor contenido de humedad (61.90\%).

Palabras Clave:

Ortiga, Hidalgo, Coagulante Vegetal, Quimosina

\section{Introduction}

Cheese is a food product of great consumption worldwide, which has great nutritional, functional and physicalchemical characteristics (Ramírez-López \& Vélez-Ruiz, 2012). In Mexico, the cheese production increases due to its high consumption of this product, being mainly the fresh cheeses the ones of greater demand due to its relative easy of elaboration and its great popularity in the country. For the manufacture of all types of cheeses, the main and basic step is the coagulation of milk, for which coagulants are used from various sources such as vegetable, enzymatic and animal.

The animal rennet is obtained from the fourth stomach of the lactating bovine, being the main source that contains the aspartic enzyme chymosin, component that produces the destabilization of the casein micelles in the milk obtaining as a result the coagulation, this enzymatic

\footnotetext{
a Universidad Autónoma del Estado de Hidalgo, Instituto de Ciencias Agropecuarias, Email: urielgonzalezlemus@gmail.com, 
preparation is which has been widely used for a long time (Lo Piero et al., 2002). The increase in cheese production and the shortage of the rennet has led to continuous research to discover new alternate sources of coagulants that substitute animal, as are the microbial curds obtained from bacteria ( $E$. Coli) genetically modified (Egito et al., 2007), or the coagulants obtained from fruit and vegetable sources. In Mexico, as in other countries, interest has been generated on the research of coagulants of plant origin with the purpose of creating an alternative on existing ones such as enzymatic (microbial) rennet or animal rennet, which are the most used in the dairy industry and thus potentiate the use of vegetable rennets for the manufacture of all types of cheese, such is the case of Martínez et al. (2013) who used the vegetable coagulant of the plant Solanum eleagnifolium for the preparation of the asadero cheese which is produced in the state of Chihuahua. Due to the mentioned, in the state of Hidalgo is located the nettle (Euphorabiace Cnidoscolus aconitifolius) a plant that grows in tropical climates typical of the municipalities of Huautla, Huejutla, Tenango de Doria, Zacualtipan and Tianguistengo which is used for the elaboration of fresh artisan cheese. Due to this, the aim is to compare the physico-chemical parameters of the cheeses made with the coagulant extract of the leaf of the nettle at different concentrations $(1.0 \%$ and $0.75 \%)$ with a cheese made with animal rennet (chymosin).

\section{Materials and methods}

\section{Obtaining coagulant extract}

The extract was obtained following the methodology proposed by Ahmed et al. (2009) with some modifications. $50 \mathrm{~g}$ of leaf previously minced with $20 \mathrm{~mL}$ of distilled water was added, later it was milled in Torrey industrial blender (Lp-12, USA). The crushed mixture was filtered with the help of a Spanish linen cloth. The obtained vegetal extract was stored in aseptic plastic containers and kept in refrigeration at a temperature of $4^{\circ} \mathrm{C}$ until its use.

\section{Preparation of panela type cheeses}

For the elaboration of the cheeses bovine milk (Raza Holstein) was acquiered from the plant PROUNILAC located in the Institute of Agricultural Sciences (ICAp), which belongs to the Autonomous University of the Hidalgo State (UAEH). The cheese control was elaborated following the procedure described by Talib et al. (2009) with some modifications. The elaboration of the cheeses with the treatments of leaf extract $(1.0 \%$ and $0.75 \%)$ was used the technique described by Nasr et al. (2016) with some modifications, where milk was incubated to $90^{\circ} \mathrm{C}$ and was added calcium chloride and the leaf extract $(1.0 \%$ and $0.75 \%$ ), was agitated and when precipitation of the curd was obtained, sodium chloride was added. Later it was pressed, molded and packed for its conservation where 5 cheeses of each treatment were elaborated. The cheeses were stored at a temperature of $4^{\circ} \mathrm{C}$ until their analysis.

\section{Physico-chemical analysis of panela cheeses}

Cheese samples made with different concentrations of leaf extract $(1.0 \%$ and $0.75 \%)$ and the control made with animal rennet (Chymosin) were analyzed in triplicate for each test. For the determination of moisture present in the samples, it was calculated by the weight loss produced by the drying of hot air flow in an oven at $50^{\circ} \mathrm{C}$ for 48 hours according to the AOAC (1997 Official Method 925.09); the fat content by the Gerber method (AOAC,1997; Method 18 ); the ash content was determined by the incineration of the samples in muffle at $550{ }^{\circ} \mathrm{C}$ for $8 \mathrm{~h}$ (AOAC, 1997; Official Method 923.03); and the protein content by the micro Kjeldahl technique (AOAC, 1997; Official Method 920.123).

\section{Statistical analysis}

An ANOVA analysis was carried out to compare means with a significant difference, setting a confidence interval of $95 \%$. Statistical correlations were performed by Tukey method with a level of significance $(p<0.05)$, using the statistical software IBM SPSS Statistics (IBM® SPSS ${ }^{\circledR}$ 2016 version 18, Armonk, USA).

\section{Results and discussion}

Table 1 shows that moisture content in the control treatment was the highest percentage (66.98\%) while treatments made with the plant extract at different concentrations $(1.00 \%$ and $0.75 \%)$ had lower moisture content $(61.99 \%$ and $61.06 \%$ respectively) with respect to the control, significant differences exist with $p<0.05$. Where moisture content in the control treatment was the highest percentage $(66.98 \%)$ while treatments made with the plant extract at different concentrations $(1.00 \%$ and $0.75 \%)$ had lower moisture content $(61.99 \%$ and $61.06 \%$ respectively) Regarding control, significant differences exist with $p<0.05$. A similar case was reported in the research by Chávez et al. (2016) where they made a fresh cheese with the vegetable extract obtained from the berries of Solanum elaeagnifolium which presented a lower percentage of humidity $(67.66 \%)$ compared to the control treatment made with chymosin $(68.64 \%)$ due to the fact that the milk protein precipitates more quickly with plant extracts due to the presence of one or more aspartic enzymes, resulting in a greater proteolytic activity favoring the formation of a smaller clot that allows the exit of the whey with greater speed, resulting in greater compaction between the different casein fragments and reflecting a lower moisture content. The fat in the cheeses made with the leaf extract at different concentrations $(1.00 \%$ and 
$0.75 \%$ ) had a higher fat content $(20.0 \%$ and $19.25 \%$ respectively) compared to the control treatment (17.50\%), there being significant differences among the treatments, this difference is reflected because the treatments made with leaf extract had lower moisture content compared to the control, so the percentage of solids is increased. The fat percentage of the cheeses made with the different leaf extract concentrations $(1.0 \%$ and $0.75 \%)$ was higher (20.0\% and $19.25 \%$ respectively) than the amount of fat in the cheese (18.0\%) made with Solanum dubium extract as a coagulant by Talib et al. (2009).

On the other hand, the ash content between the treatments showed significant differences with respect to the control with $p<0.05$, the cheese made with $1 \%$ extract had the highest ash content $(3.00 \%)$ compared to the control (2.17\%) elaborated with animal rennet (chymosin). The increase in ash content can be attributed to the concentration of salts and minerals present in the extract, since it can be seen that increasing the volume of the leaf coagulant extract increases the ash content. The results obtained from the treatments elaborated with leaf extract $(1.00 \%$ and $0.75 \%)$ were lower $(3.0 \%$ and $2.38 \%)$ in comparison to the results obtained by Acevedo et al. (2010) in artisanal fresh cheese which presented a higher percentage of ash (3.2\% and 3.5\%).

Figure 1 shows the amount of protein of the cheeses made with leaf extract at $1 \%(18.16 \%)$ and $0.75 \%(16.74 \%)$ contained higher protein compared to the control cheese $(15.18 \%)$ made with chymosin, showing differences significant of the treatments with leaf extract and the control with $p<0.05$. The difference in the percentage of protein in the cheeses is related to the moisture content, according to Mazorra-Manzano et al. (2013) explains that a cheese is a complex structure formed by protein, fat, minerals and water, which is in constant rearrangement originated by the syneresis, which is the loss of whey that migrates from the interior of the cheese to the outside, which generates the increase of the solids present in the cheese such as protein, minerals and fat.

\section{Conclusion}

In the physico-chemical analyzes it was observed that the cheeses elaborated with the leaf extract of the nettle (Euphorabiace Cnidoscolus aconitifolius) at a concentration of $1 \%$ had the lowest moisture content $(61.99 \%)$, the highest percentage of protein (18.16\%) and fat $(20.0 \%)$ compared to other treatments. The leaf extract of the nettle. used as a coagulating agent is a good alternative that can generate a fresh cheese with better physical-chemical characteristics in comparison to one made with an animal coagulant (chymosin) where it is increased protein, fat and ash content.

\section{References}

1 AOAC. (1997). Official Methods of Analysis of the Association of Official Analytical Chemist International.Method 925.09.

2 AOAC. (1997). Official Methods of Analysis of the Association of Official Analytical Chemist International. Method 923.03.

3 AOAC. (1997). Official Methods of Analysis of the Association of Official Analytical Chemist International. Method 962.09.

4 AOAC. (1997). Official Methods of Analysis of the Association of Official Analytical Chemist International. Method 957.01.

5.- AOCS. (1993). Official Methods and Recommended Practices of the American oil chemists society. 4th Ed. Champaign.

6.- Ahmed, I. A. M., Morishima, I., Babiker, E. E., \& Mori, N. (2009). Characterisation of partially purified milk-clotting enzyme from Solanum dubium Fresen seeds. Food Chemistry, 116(2), 395-400. doi: https://doi.org/10.1016/j.foodchem.2008.11.072,

7.- Chávez-Garay, D. R., Gutiérrez-Méndez, N., Valenzuela-Soto, M. E., \& García-Triana, A. (2016). Partial characterization of a plant coagulant obtained from the berries of Solanum elaeagnifolium. CyTA - Journal of Food, 14(2), 200-205. doi:10.1080/19476337.2015.1080763.

8.- Egito, A. S., Girardet, J. M., Laguna, L. E., Poirson, C., Mollé, D., Miclo, L., Gaillard, J. L. (2007). Milk-clotting activity of enzyme extracts from sunflower and albizia seeds and specific hydrolysis of bovine $\kappa$-casein. International Dairy Journal, 17(7), 816-825. doi: https://doi.org/10.1016/j.idairyj.2006.09.012

9.- Lo Piero, A. R., Puglisi, I., \& Petrone, G. (2002). Characterization of "lettucine", a serine-like protease from Lactuca sativa leaves, as a novel enzyme for milk clotting. J Agric Food Chem, 50(8), 2439-2443

10.- Martínez-Ruiz, N. d. R., Enriquez, S. F., Vázquez-Nájera, R. E., \& López-Díaz, J. A. (2013). Microbiological Quality of Asadero Cheese Manufactured with a Plant Based Coagulant from Solanum elaeagnifolium. Food and Nutrition Sciences, Vol.04No.07, 7. doi: 10.4236/fns.2013.47A009

11.- Mazorra-Manzano, M. A., Perea-Gutiérrez, T. C., Lugo-Sánchez, M. E., Ramirez-Suarez, J. C., Torres-Llanez, M. J., González-Córdova, A. F., \& Vallejo-Cordoba, B. (2013). Comparison of the milk-clotting properties of three plant extracts. Food Chemistry, 141(3), 1902-1907. doi: https://doi.org/10.1016/j.foodchem.2013.05.042

12.- Nasr, A. I. A. M., Ahmed, I. A. M., \& Hamid, O. I. A. (2016). Characterization of partially purified milk-clotting enzyme from sunflower (Helianthus annuus) seeds. Food Science \& Nutrition, 4(5), 733-741. doi: doi:10.1002/fsn3.338

13.- Ramírez-López, C., \& Vélez-Ruiz, J. (2012). Quesos frescos: propiedades, métodos de determinación y factores que afectan su calidad. Temas selectos de ingenieria de alimentos, 6(2), 131-148. 


\begin{tabular}{lcccc}
\hline & Moisture & Fat & Proteín & Ashes \\
\hline Control & $66.98 \pm 0.15^{\mathrm{b}}$ & $17.50 \pm 0.70^{\mathrm{a}}$ & $15.18 \pm 0.34^{\mathrm{a}}$ & $2.17 \pm 0.002^{\mathrm{a}}$ \\
\hline T 0.75\% & $61.06 \pm 0.04^{\mathrm{a}}$ & $19.25 \pm 0.24^{\mathrm{b}}$ & $16.74 \pm 0.33^{\mathrm{bc}}$ & $2.38 \pm 0.030^{\mathrm{b}}$ \\
\hline T $\mathbf{1 . 0 0} \%$ & $61.99 \pm 0.31^{\mathrm{a}}$ & $20.00 \pm 0.2^{\mathrm{ab}}$ & $18.16 \pm 0.49^{\mathrm{cd}}$ & $3.00 \pm 0.058^{\mathrm{c}}$ \\
\hline
\end{tabular}

Table 1. Physical-chemical parameters of the different treatments of panela-type cheese made with leaf extract from the nettle (Euphorabiace Cnidoscolus aconitifolius). The results are presented as means \pm standard deviation. The different letters $(a, b, c)$ in each column indicate differences between treatments. 